\title{
Bonaventure and the Question of a Medieval Philosophy
}

\author{
ANDREAS SPEER \\ Thomas-Institut, Köln
}

\section{INTRODUCTION}

Can one speak coherently of Bonaventure's philosophy? Or is such an idea nothing more than a modern hermeneutical fancy? The arguments against the view that Bonaventure has a philosophy are of diverse origin. Certain influential students of medieval intellectual history have advanced the following argument: it is improper, a kind of basic category error, to speak of philosophy as an autonomous discipline practiced within medieval faculties of theology. This historiographical tendency derives from certain nineteenth-century continental ideas about enlightenment, progress, and secularization. As the French Revolution is viewed as the birth of modernity, so, on this view, the Condemnations of 1277 beget philosophy as an "autonomous" discipline within the Middle Ages. "Autonomous" in this context means little more than "independent from theology." In the writings of the Arts-masters at the University of Paris, so the argument goes, one can find enlightenment before the Age of Enlightenment, a renascence before the Renaissance, and a humanism before Humanism. ${ }^{1}$

If we are to pose hermeneutical questions of the sort on which this historiographical hypothesis turns, we ought perhaps begin by asking the following general question: what is philosophy in the Middle Ages? Or, put more concretely: what remains of medieval philosophy, if we include in our account of the discipline of philosophy the notion that what the theologi do

Earlier versions of this article were presented as lectures at Boston College, Yale University, St. Bonaventure University, and at the University of Notre Dame. I would like to thank the participants of these sessions for their comments.

1. See, for example, Kurt Flasch, Aufklärung im Mittelalter? Die Verurteilung von 1277 (Mainz, 1989); Luca Bianchi, Il Vescovo e i Filosofi. La condanna parigina del 1277 e l'evoluzione dell' Aristotelismo scolastico (Bergamo, 1990); Alain de Libera, Penser au Moyen Age (Paris, 1991). The basic study concerning the condemnations is still Roland Hissette, Enqête sur les 219 articles condamnés à Paris le 7 Mars 1277, Philosophes Médiévaux 22 (Paris, 1977); see also the critical remarks of R. Hissette, "Note sur la réaction anti-rationaliste' d'Etienne Tempier," Revue philosophique de Louvain 88 (1990): 395-403. 
is by definition not philosophical?2 To be sure, Bonaventure, like Albert the Great, Thomas Aquinas, Alexander of Hales, and John Duns Scotus, was a member of a faculty of theology. He and his colleagues understood themselves as "theologi."

In addition to the sources discussed above, Dante Aligheri's works offer another nearly contemporary source for understanding how these medieval thinkers conceived of themselves and their works. In the fourth sphere of Paradiso, the sphere of the sun, Dante introduces Thomas Aquinas and Bonaventure accompanied by a number of their contemporaries and predecessors-figures, for the most part, with reputations as philosophers as well as theologians. Bonaventure's companions include Hugh of St. Victor, Peter Comestor, and Peter of Spain, the prophet Nathan and John Chrysostom, Anselm of Canterbury and Donatus, Rhabanus Maurus and Joachim of Fiore. ${ }^{3}$ There seems here to be no sense of a distinction between "authentic" philosophers and "mere" theologians. While, in all likelihood, Dante was personally acquainted with the University of Paris at the beginning of the fourteenth century, his Paradise appears to assume nothing like the rigid distinction between philosophers and theologians presupposed by intellectual historians like De Libera, Imbach, and Flasch.

If one re-reads medieval intellectual history on the assumption that to practice philosophy is something like "to exercise pure human reason," one is left with the difficult conclusion that these thinkers did not practice philosophy. Etienne Gilson-he was also a distinguished Dante scholar-must be turning over in his grave. It was his life's work to discourage precisely this sort of anachronistic use of modern notions of philosophy as a litmus test for the intellectual seriousness of medieval thinkers. Gilson sought, that is to say, to understand the medieval way of thinking, to describe its proper "spirit." It is interesting to note that the two figures he chose to represent the peculiarly medieval study of philosophy were Thomas Aquinas and Bonaventure. Shortly after writing his seminal work on the importance of medieval thought in Descartes's philosophy, his Index scolastico-cartésien, Gilson began research on these two medieval philosophers. Though interrupted in his efforts by the First World War, he went on to produce three clearly related works: Saint Thomas d'Aquin, Le Thomisme, and La philosophie de saint Bonaventure. ${ }^{5}$

To come immediately to the point, I might invoke Gilson's conclusion to this last work - a vital and unsurpassed study of Bonaventure's mind-and

2. See Jan A. Aertsen, "Gibt es eine mittelalterliche Philosophie?" in Philosophie und geistiges Erbe des Mittelalters, ed. A. Speer (Köln: 1994), 13-30; see also Philosophisches Jahrbuch 102 (1995): 161-76.

3. Dante Aligheri, La Commedia divina, Paradiso XII, 133-41.

4. See Etienne Gilson, L'esprit de la philosophie médiévale, Études de philosophie médiévale 33, 2d ed., (Paris: J. Vrin, 1944).

5. Gilson's Index scolastico-cartésien and his thesis La liberté chez Descartes et la théologie were published in 1913. The first editions of the books on Aquinas and Bonaventure were published between 1919 and 1925. See Laurence K. Shook, Etienne Gilson, The Etienne Gilson Series 6, (Toronto: 1984) esp. chaps. 4 and 7. 
neatly resolve our initial question and conclude this article. In that conclusion, Gilson characterizes Bonaventure's philosophy as perhaps the greatest synthesis of Christian thought ever realized, and the most peculiarly medieval one. From a "rationalistic" perspective, however, Bonaventure's philosophy would not appear to be "philosophical" at all, since, as Gilson points out, the Franciscan refuses to accept the Aristotelian Organon as the sole criterion of truth in respect of philosophical questions. ${ }^{6}$ For Gilson, this refusal constitutes the decisive element differentiating Bonaventure's thought from those of Albert the Great and Thomas Aquinas. It also explains why Bonaventure participates in the great intellectual debates of his time in a manner very different from the two great Dominicans.

One scholar give an authoritative reply to Gilson's attempt to portray Bonaventure's thought as "Franciscan wisdom" and "the metaphysics of Christian mysticism." 7 In his influential history of thirteenth-century philosophy, Fernand van Steenberghen emphasizes the institutional locus of Bonaventure's writings-they are the products of a professor at a university. Although van Steenberghen means to foreground Bonaventure's involvement in the intellectual debates of the thirteenth century, he has a very qualified view of the domain of Bonaventure's philosophy, indeed one that seems overly-restricted and weak. He sees Bonaventure's approach to philosophy as eclectic at its roots; Bonaventure's real contributions, van Steenberghen claims, are theological in nature. 8

I could go on reporting the colorful history of approaches to the thought of Bonaventure. To do so would not be without interest, because the history of speculation about Bonaventure parallels certain trends within the received understanding of medieval philosophy in general. The fact that Bonaventure's thought counts among the most neglected subjects in the current study of medieval philosophy is not as appreciated as it should be. Apart from a flurry of interest in 1974-the heady 700th anniversary of the deaths of both Bonaventure and Aquinas-what study there has been of Bonaventure has been of his role within the Franciscan spiritual tradition and in the history of the mendicant movement. I am sorry to say that, in my opinion, the topos of the "Franciscan vocation" of Bonaventure all too often stands in the place of serious and precise historical research. We know very little, for example, about the sources and traditions influencing Bonaventure around 1235, when he began his academic career as a student in Paris

6. Etienne Gilson, La philosophie de saint Bonaventure (Paris: 1924), pp. 387, 396. Gilson had first approached the topic as a private research project during his stay in Lille in 1913. As L. K. Shook (Etienne Gilson, pp. 126-29) points out in his biography, Gilson's presentation of Bonaventure as an anti-thomist Christian philosopher gave rise to great controversies among both Catholic and non-Catholic university philosophers.

7. See in particular the section of Gilson's introductory chapter titled "Le problème bonaventurien," pp. 59-75.

8. Fernand van Steenberghen, La théologie au XIII siècle; 2nd. ed. (Paris: 1991), chap. V. 
(the year, you will note, before Philip the Chancellor died). It is clear, to go further, that Bonaventure heard the lectures of Alexander of Hales, yet no study exists of the relationship between Alexander and Bonaventure.

Allow me to add here a few remarks about the Quaracchi-edition. The work of the Leonine editors of Thomas Aquinas has clearly become an engine driving an increasingly deep and more sophisticated historical and systematic understanding of Thomas's thought. Ironically, the much more timely completion of the "critical" edition of Bonaventure's opera omnia, completed by the eminent Collegio di S. Bonaventura in Quaracchi, has had an unfortunate side-effect. ${ }^{9}$ One can find no reference to the fruits of the great international edition-projects of recent years-the Aristoteles latinus, Avicenna latinus, Averrois opera, not to mention the works of his near contemporaries Thomas Aquinas and Albert the Great, and successors Giles of Rome, Henry of Gent, and John Duns Scotus-in the Quaracchi texts. The historical basis for any study of Bonaventure's relationship to the debates of his day is thus from the outset tightly circumscribed.

I will conclude these rather extensive but, I trust, not uninformative introductory remarks by highlighting three areas that I see as important for future research on Bonaventure:

1. As a body of texts, I consider the academic writings of Bonaventure before his election as the seventh Minister General of the Franciscan Order to be of singular importance for charting the currents at Paris within the first half of the thirteenth century. They reflect the influence of the pivotal Parisian magistri of this period, like Philip the Chancellor, Richard Rufus, and, above all, Alexander of Hales. Such study, of course, would contribute significantly to a more philologically and historically solid estimation of the young Bonaventure. Why not make, for example, the works of Alexander of Hales, as reflected in his most brilliant student, the starting point of generalizations about putatively "Franciscan" positions on intellectual debates? This would certainly be preferable to some fuzzy inferences from a still fuzzier notion of "Franciscan spirituality."

2. Very little is known about the influence of the school of St. Victor in the thirteenth century. This neglect is noted with particular acuity by serious students of Bonaventure because Bonaventure's works subsequent to his election as Minister General manifest the lively influence of Victorine thought in Paris. Those who know something about the enduring institutional vitality of the school of St. Victor will not be surprised by this observation. Bonaventure seems to see the Victorine monastic model as

9. Wolfgang Kluxen, "Die geschichtliche Erforschung der mittelalterlichen Philosophie und die Neuscholastik," in Christliche Philosophie im katholischen Denken des 19. und 20. Jahrhunderts, ed. E. Coreth, W. M. Neidl, G. Pfligersdorfer (Köln: 1988), pp. 362-89, esp. 366 and 372-73; Mathias Köck, "Quaracchi-Der franziskanische Beitrag zur Erforschung des Mittelalters,” in Christliche Philosophie, pp. 390-96. 
providing a means of reconciling tensions between the desires of the intellect and the desires of the soul. ${ }^{10}$ Bonaventure's use of St. Victor affords another, more serious means of speaking about the place of Franciscan thought within the intellectual debates of the period.

3. I mention lastly the power struggles among intellectuals in the last third of the thirteenth century, which lead, first, to the condemnations issued on 10 December 1270. By that time, Bonaventure, along with Thomas Aquinas, had long been engaged in the Parisian debates. As is well known, two of Bonaventure's last great collations, On the Ten Commendments and On the Seven Gifts of the Holy Spirit, constitute a prelude to the Condemnations of 1270, while the Collations on the Sixdays offer a postlude. ${ }^{11}$ They provide insight, at a very high level, into what was really at stake. Now, Ruedi Imbach likes to style Bonaventure a kind of "ideological trailblazer" for the later, more extensive Condemnations of 1277. My answer to this kind of a historiographical "Molotov cocktail" is clear and distinct: Imbach's argument that Bonaventure's "reductio ad unum" is the blueprint for Tempier's "reductio ad papam" is without any historical or textual warrant. ${ }^{12}$

A historical perspective such as the one I am outlining shows how Bonaventure's oeuvre fits within, and reflects the principle intellectual developments of, the thirteenth century. But what, you will ask, is Bonaventure's own view? The question about Bonaventure's approach to philosophy commonly figures in the debates alluded to above as a kind of a touchstone. To answer it is to take a position on a battlefield where the lines are already tightly drawn. Let us raise the question anew: does Bonaventure have his own unique approach to philosophy? In fact, does he have a philosophy at all?

\section{TOTA NOSTRA METAPHYSICA}

My answer to these questions begins with the first collation of the Hexaemeron. The choice of this text may be surprising. In 1959, Joseph Ratzinger

10. Andreas Speer, "Von der Wissenschaft zur Weisheit. Philosophie im Übergang bei Bonaventura," in (eds.), Weisheit und Wissenschaft, ed. T. Borsche and J. Kreuzer (München: 1995), pp. 115-127; Kent Emery, Jr., "Reading the World Rightly and Squarely: Bonaventure's Doctrine of the Cardinal Virtues," Traditio 39 (1983): 183-218, esp. 214-18; Zachary Hayes, "Bonaventure. Mystery of the Triune God" in The History of Franciscan Theology, ed. K. B. Osborne (St. Bonaventure: 1994), pp. 39-125; see further, intro. of Zachary Hayes, Saint Bonaventure's Disputed Questions on the Mystery of the Trinity (New York: 1979), pp. 13-29.

11. See van Steenberghen, La théologie au XIII siècle, pp. 427-29, 472-82.

12. Ruedi Imbach, Laien in der Philosophie des Mittelalters, Hinweise und Anregungen zu einem vernachlässigten Thema, Bochumer Studien zur Philosophie 14, (Amsterdam: 1989), pp. 151-57. 
gave this text an interpretation that has stuck with it ever since: the Collationes in Hexaemeron are a kind of manifesto-the manifesto of anti-Aristotelian, anti-philosophical, anti-scholasticism. ${ }^{13}$ Now, Ratzinger's interpretation reads like the reflex reaction of a certain kind of Catholicism, and the mislabeling of this text may be the single greatest cause for the overemphasis on Bonaventure's "anti-philosophism." This is a great shame, for in no other work does he give such a systematic and concise presentation of his general approach to philosophy, as one can see immediately in the first Collatio.

Quoting Colossians 2:3, Bonaventure relates the seven-fold treasure of our knowledge and wisdom to Christ. $\mathrm{He}$ is the central point in a sevenfold sense: in terms of essence, nature, distance, doctrine, moderation, justice, and concorde. ${ }^{14}$ In the very same context, Bonaventure observes that the first science-related to essence-from which all inquiry must begin, is metaphysics. This is because metaphysics proceeds from the consideration of the principles of created and particular substances to the consideration of the universal and uncreated substance; that is, to that Being (ad illud esse) that has the character of a principle, a center, and a goal (ratio principii, medii et finis). ${ }^{15}$ For this reason, metaphysics cannot be understood as an investigation proceeding from the consideration of a purely formal subject, like the "ens inquantum ens" (the being as such). Rather, it follows the principle of causal exemplarity. From the very beginning, that is, being must be understood in a twofold way. It is both "esse ex se et secundum se et propter se" (being as subsistent, self-modeled, and self-intended) as well as "esse ex alio et secundum aliud et propter aliud" (being as contingent, modeled on another, and tending to another). It is the task of metaphysics to explain the relationship between per se (subsistent) being and contingent being. ${ }^{16}$ Consequently, the proper subject of metaphysics 1959).

13. Joseph Ratzinger, Die Geschichtsphilosophie des hl. Bonaventura (München:

14. Collationes in Hexaemeron 1,11, V 331a: "Propositum igitur nostrum est ostendere, quod in Christo sunt omnes thesauri sapientiae et scientiae Dei absconditi, et ipse est medium omnium scientiarum. Est autem septiforme medium, scilicet essentiae, naturae, distantiae, doctrinae, modestiae, iustitiae, concordiae. Primum est de consideratione metaphysici, secundum physici, tertium mathematici, quartum logici, quintum ethici, sextum politici seu iuristarum, septimum theologi."

15. Collationes in Hexaemeron 1,11, V 331 b: "Metaphysicus autem, licet assurgat ex consideratione principiorum substantiae creatae et particularis ad universalem et increatam et ad illud esse, ut habet rationem principii, medii et finis."

16. Collationes in Hexaemeron 1,12, V 331ab: "Primum ergo medium est essentiae aeternali generatione primarium. Esse enim non est nisi dupliciter: vel esse, quod est ex se et secundum se et propter se, vel esse, quod est ex alio et secundum aliud et propter aliud. Necesse etiam est, ut esse, quod est ex se, sit secundum se et propter se. Esse ex se est in ratione originantis; esse secundum se in ratione exemplantis, et esse propter se in ratione finientis vel terminantis; id est in ratione principii, medii et finis seu termini." 
is to think about being as the cause in an exemplary manner of all that exists (esse in ratione omnia exemplantis). The metaphysician thus also considers being as a productive principle (ratione principii omnia originantis) or ultimate goal (ratione ultimi finis). This is the point of interaction shared by the metaphysician, the physicist, and the moral philosopher. ${ }^{17}$ With the phrase "Haec est tota nostra metaphysica" (that is our entire metaphysics), Bonaventure introduces a neat list of topics delineating the proper field of study of the ideal philosopher. The topics included in Bonaventure's metaphysics are: "emanation" (emanatio), "exemplarity" (exemplaritas), and "consummation" (consummatio), by which he means being "as illuminated by the spiritual radiation and reduced to the highest" (illuminari per radios spirituales et reduci ad summum). ${ }^{18}$

Bonaventure draws several consequences here, which I will summerize in four points. Each is important for the accurate reconstruction of his thought:

1. He claims that the existence of truth can never be denied because without truth, nothing can be considered or understood ("nec aliquo modo aliqua veritas sciri potest nisi per illam veritatem"). ${ }^{19}$

2. To "know something," in the strict sense of the term, is to understand it with certainty. For Bonaventure, this means to understand it by means of, or in relationship to, an immutable truth ("nihil sciatur nisi per veritatem immutabilem"). ${ }^{20}$

3. The intelligibility of things corresponds to their ontological structure, and vice-versa ("idem est principium essendi et cognoscendi"). ${ }^{21}$

4. The mind's first concept is the "esse divinum"; the divine being is an $a$ priori condition for the entire possibility of knowing ("esse enim divinum primum est, quod venit in mente").22

17. Collationes in Hexaemeron 1,13, V 331 b: "Metaphysicus enim assurgit ad illud esse considerandum in ratione principii omnia originantis; et in hoc convenit cum physico, qui origines rerum considerat. Assurgit etiam ad considerandum illud esse in ratione ultimi finis; et in hoc convenit cum morali sive ethico, qui reducit omnia ad unum summum bonum ut ad finem ultimum, considerando felicitatem sive practicam sive speculativam. Sed ut considerat illud esse in ratione omnia exemplantis, cum nullo communicat et verus est metaphysicus."

18. Collationes in Hexaemeron 1,17, V 332b: "Hoc est medium metaphysicum reducens, et haec est tota nostra metaphysica: de emanatione, de exemplaritate, de consummatione, scilicet illuminari per radios spirituales et reduci ad summum. Et sic eris verus metaphysicus."

For the genesis of Bonaventure's metaphysical thought, see my article "Metaphysica reducens. Metaphysik als erste Wissenschaft im Verständnis Bonaventuras," Recherches de Théologie ancienne et médiévale 57 (1990): 142-82.

19. Collationes in Hexaemeron 1,13, V 331b.

20. Collationes in Hexaemeron 1,13, V 331b.

21. Collationes in Hexaemeron 1,13, V 331b.

22. Collationes in Hexaemeron 10,6, V 378a. 
We might call these basic teachings, to employ a formulation of Romano Guardini, the "system-constituting" elements of Bonaventure's thought ("systembildende Elemente"). ${ }^{23}$ I will attempt to illustrate the role that they play through an analysis of three central Bonaventurian hermeneutical terms: certitudo, illuminatio, and reductio.

\section{CERTITUDO}

Bonaventure opens his disputed questions on the mystery of the Trinity, his Quaestiones disputatae de mysterio Trinitatis, by pointing out what the conditions are, in addition to the possession of divine grace, for the study of the Trinity. The first two conditions are what Bonaventure calls the "foundation of certain knowledge," and the "foundation of knowledge by faith." ${ }^{4}$ In introducing these terms, Bonaventure raises questions about what these foundations are, and how they can be examined. This discussion of the conditions for the study of the Trinity is very typical of Bonaventure's writing; the search for certitude is a Bonaventurian leitmotif. This also says much about Bonaventure's habits as a thinker, and suggests an answer as to his view of the status of philosophy.

The twofold distinction concerning the foundation of knowledge evokes the distinction between philosophical knowledge dealing with a knowledge of the truth that can be scrutinized as "certain knowing" ( $u t$ scrutabilis notitia certa) and theological knowledge containing a knowledge of truth that is worthy of belief by "pious knowing" ( ut credibilis notitia pia).$^{25}$ While it may seem strange to find arguments for the indispensable need for philosophy in an introduction to disputed questions on the mystery of the Trinity, Bonaventure defines philosophy's role very clearly; it follows from his ideas about certainty. Philosophy undertakes no less than to disclose the

23. Romano Guardini, Systembildende Elemente in der Theologie Bonaventuras. Die Lehre vom Lumen mentis, von der Gradatio entium und der Influentia sensus et motus, Studia et Documenta Franciscana 3, ed. W. Dettloff (Leiden: 1964).

24. De Mysterio Trinitatis prol., V 45ab: "Volentes circa mysterium Trinitatis aliquid indagare, divina praevia gratia, duo praemittimus tanquam praeambula: quorum primum est fundamentum omnis cognitionis certitudinalis; secundum est fundamentum omnis cognitionis fidelis. Primum est, utrum Deum esse sit verum indubitabile. Secundum est, utrum Deum esse trinum sit verum credibile."

25. See Collationes de septem donis Spiritus Sancti 4,5 (see n. 73); this is the point of reference for the Bonaventurian doctrine of the "vestigia Trinitatis" which admit of discovery by philosophical scientia; see also 4,11, V 475b: "Ostendit igitur Salomon se pervenisse ad triformem descriptionem scientiae philosophicae, scilicet ad descriptionem scientiae rationalis, moralis et naturalis et ad triformen descriptionem quarumlibet istarum. Qui haberet descriptionem istarum scientiarum secundum veritatem, maximum speculum haberet ad cognoscendum, quia nihil in aliqua istarum scientiarum, quod non importet vestigium Trinitatis. Illud esset facile ostendere, sed longum esset." 
foundation of all knowledge. Since theology requires a firm foundation in order to be certain, it follows that theology needs philosophical analysis. ${ }^{26}$

Bonaventure's grounds for this view seem to lie in his analysis of the human intellect. To the extent that reason must be understood as a kind of image ("in quantum tenet rationem imaginis"), the knowledge of truth is inherent in the rational soul ("mens rationalis"). ${ }^{27}$ You may already see the relevance here of Bonaventure's theory of illumination-we will return to it shortly. What is the foundation for each certain act of knowing to which the natural appetite leads the rational soul? Bonaventure begins with an analogy based on an analysis of a simple semantic structure. That which is most certain "secundum se". is that which is first and most immediately true. In "that which is first and most immediately true," therefore, not only is the cause of the predicate included in the subject, but it is the fullness of being itself which is predicated and which is the subject about which the predication is made. Now, a union of beings that are extremely distant from each other is entirely repugnant to our mind, for no intellect is able to think that one and the same thing exists and does not exist at the same time and in the same respect. Therefore also the division of something that is entirely one and undivided is inconceivable. "Hence to say that a being which possesses the highest degree of existence is non-existent involves a most evident fallacy, just as is the case in saying that to exist and not exist are one and the same." 28 For this reason, Bonaventure concludes, it is a perfectly

26. De Mysterio Trinitatis qu. 1 a. 1, V 45a: "Quaeritur ergo primo, utrum Deum esse sit verum indubitabile? Et quod sic, ostenditur triplici via. Prima est ista: omne verum omnibus mentibus impressum verum indubitabile. Secunda est ista: omne verum, quod omnis creatura proclamat, est verum indubitabile. Tertia est ista: omne verum in se ipso certissimum et evidentissimum est verum indubitabile." See in detail, Andreas Speer, Triplex Veritas. Wahrheitsverständnis und philosophische Denkform Bonaventuras, Franziskanische Forschungen 32, (Werl/Westf: 1987), pp. 84-86.

Because it deals with its objects on the basis of natural or acquired knowledge, philosophy is also able to offer a "mirror" to a theology founded on the evidence of faith, which reflects the divine mysteries; see Breviloquium, prol. § 3, V 205a: "Philosophia quidem agit de rebus, ut sunt in natura seu in anima secundum notitiam naturaliter insitam vel etiam acquisitam; sed theologia tanquam scientia super fidem fundata et per Spiritum sanctum revelata agit et de eis, quae spectant ad gratiam et gloriam et etiam ad Sapientiam aeternam. Unde ipsa substernens sibi philosophicam cognitionem et assumens de naturis rerum, quantum sibi opus est ad fabricandum speculum, per quod fiat reprasentatio divinorum; quia scalam erigit, quae in sui infimo tangit terram, sed in suo cacumine tangit caelum." See Speer, Metaphysica reducens, pp. 155-59.

27. De Mysterio Trinitatis, qu. 1 a. 1 c, V 49a: "Est enim certum ipsi comprehendenti, quia cognitio huius veri innata est menti rationali, in quantum tenet rationem imaginis, ratione cuius insertus est sibi naturalis appetitus et notitia et memoria illius, ad cuius imaginem facta est, in quem naturaliter tendit, ut in illo possit beatificari."

28. De Mysterio Trinitatis qu. 1 a. 1 c, V 49b: "Est etiam illud verum certissimum secundum se, pro eo quod est verum primum et immediatissimum, in quo non tantum causa praedicati clauditur in subiecto, sed id ipsum est omnino esse, quod 
evident judgment that the first and highest being must exist ("sic primum et summum ens esse est evidentissimum in sua veritate"). ${ }^{29}$ But this first and highest being is God.

This argument becomes easier to follow if one correctly understands the meaning of the word "God" for Bonaventure in this context. Put briefly, he is speaking of Anselm's God, that being "greater than which none can be conceived." Bonaventure concludes that it is absolutely certain that this God exists. This God is the first understood, the "primum cognitum" of the human intellect. As such, He is present to every soul and every intellect as the a priori condition of all knowing. ${ }^{30}$ This insight into the necessity of God's existence is not one that our intellects in some way "develop." Rather, it is the product of a "plena resolutio" or a complete analysis, that is, it arises from the reduction of relative predicates to absolute predicates. ${ }^{31}$ In the process, the intellect becomes aware of its own foundation. We do not deny that Bonaventure builds his argument along the via Anselmi. Nor do we overlook the transcendental element of Bonaventure's approach. Being in general is conceived by means of non-contradiction, that is, by the same means by which the intellect comprehends its first concepts, that is, being and one. Bonaventure's use of the indivisio-model to account for the ratio of the "unum," you will note, bespeaks the strong influence of Philip the Chancellor's masterpiece, his SUMMA DE BONO. ${ }^{32}$

Bonaventure's a priori foundation of human knowledge should not, however, be taken as a blanket guarantee of certainty with respect to every kind of knowledge. We can see this in Bonaventure's first great disputation

praedicatur, et subiectum, quod subiicitur. Unde sicut unio summe distantium est omnino repugnans nostro intellectui, quia nullus intellectus potest cogitare, aliquid unum simul esse et non esse; sic divisio omnino unius et indivisi est omnino repugnans eidem, ad per hoc sicut idem esse et non esse, simul summe esse et nullo modo esse est evidentissimum in sua falsitate."

For the translation see Zachary Hayes, trans. and ed., Disputed Questions on the Mystery of the Trinity (St. Bonaventure, 1979), pp. 116.

29. De Mysterio Trinitatis qu. 1 a. 1 c, V 49b.

30. De Mysterio Trinitatis qu. 1 a. 1 c, V 50a: "Sed ab eo intellectu, qui plene apprehendit significatum huius nominis Deus, cogitando Deum esse, quo maius cogitari potest, non solum non dubitari, an Deus sit, sed etiam nullo modo potest cogitari Deum non esse."

31. See the "secunda via," which follows "ex decem conditionibus et suppositionibus per se notis," the so-called disjunctive transcendentals: De Mysterio Trinitatis qu. 1 a. 1 arg. 11-20, V 4b-47b. See further the second demonstration in the corpus articuli "per privationem defecti", the third criterion is an incorrect analysis: "quantum ad defectum in actu resolvendi incidit dubitatio, quando intellectus carnalis nescit resolvere [...] usque ad substantiam incorpoream nec usque ad rerum prima principia" (De Mysterio Trinitatis qu. 1 a. 1 c, V 49b).

32. See in particular Philipp the Chancellor, Summa de bono, vol. II, Corpus philosophorum medii aevi II; ed. N. Wicki, (Bern: 1985), pp. 3-36 see on this point, Jan A. Aertsen, Medieval Philosophy and the Transcendentals: The Case of Thomas Aquinas, Studien und Texte zur Geistesgeschichte des Mittelalters 52, (Köln: 1996), pp. 25-40, esp. 30-37 
on the knowledge of Christ, his Quaestiones disputatae de scientia Christi, which he undertook shortly after incepting as an ordinary master. Bonaventure discusses this question in his pivotal fourth quaestio: "Is what is known by us with certainty known in the eternal Ideas themselves?"33 Bonaventure distinguishes as the two conditions for every certain knowledge an infallibility on the part of the subject, and an immutability on the part of the object. ${ }^{34}$ The operative question here is: how can one know with certainty what something is? Bonaventure's answer is by knowing it completely, that is, under the conditions that cover both the object known and the subject knowing. ${ }^{35}$ But how can this requirement be met?

At the beginning of the fourth question, Bonaventure discusses two positions, both of which he considers inadequate and erroneous. It is not the case that certain knowledge can exist only in the intelligible world of the eternal prototype, 36 nor can one speak merely of the "influence" of the ratio aeterna on human knowing. It serves as a kind of eternal standard, without it being the case, however, that ratio aeterna itself can ever be attained. ${ }^{37}$ But created truth (veritas creata) is not merely unchangeable, it is unchangeable as a consequence of a foundational condition. Bonaventure thus seeks a third way between the two rejected positions:

In order to achieve with necessity a knowledge that lays claim to certainty, one seeks an eternal standard for guidance and direction, not [for use] by itself and in its perfect clarity, but together with a created standard, and in such a way that it is to some degree glimpsed by us even in our state of imperfection. 38

33. Quaestiones disputatae de scientia Christi qu. 4, V 17: "Utrum quidquid a nobis certitudinaliter cognoscitur, cognoscatur in ipsis rationibus aeternis."

34. Quaestiones disputatae de scientia Christi qu. 4 c, V 23b: "cognitio certitudinalis esse non potest, nisi sit ex parte scibilis immutabilitas et infallibilitas ex parte scientis."

35. Christus unus omnium magister 6, V 568b-569a: "Ad cognitionem enim scientialem necessario requiritur veritas immutabilis ex parte scientis. Omne enim, quod scitur, necessarium est in se et certum est ipsi scienti. Tunc enim scimus, 'cum causam arbitramur cognoscere, propter quam res est, et scimus, quoniam impossibile est aliter se habere'." Cf. Aristoteles, An. post. I, 271 ${ }^{\mathrm{b}} 10-11$.

36. Quaestiones disputatae de scientia Christi qu. 4 c, V 22b-23a: "Uno modo, ut intelligatur, quod ad certitudinalem cognitionem concurrit lucis aeternae evidentia tanquam ratio cognoscendi tota et sola."

37. Quaestiones disputatae de scientia Christi qu. 4 c, V 23a: "Alio modo, ut intelligatur, quod ad cognitionem certitudinalem necessario concurrit ratio aeterna quantum ad suam influentiam, ita quod cognoscens in cognoscendo non ipsam rationem aeternam attingit, sed influentiam eius solum."

38. Quaestiones disputatae de scientia Christi qu. 4 c, V 23b: "Et ideo est tertius modus intelligendi, quasi medium tenens inter utramque viam, scilicet quod ad certitudinalem cognitionem necessario requiritur ratio aeterna ut regulans et ratio motiva, non quidem ut sola et in sua omnimoda claritate, sed cum ratione creata, et ut ex parte a nobis contuita secundum statum viae." 
This eternal standard is the ars aeterna, the eternal creative art, in which things are considered according to their conceptual and specific mode of existence, that is insofar as each constitutes a trace, an image, or a similitude (secundum vestigium, imaginem et similitudinem) ${ }^{39}$

From this point of view, Bonaventure must reject the extreme positions cited in the beginning; they lead to skeptical aporia, to the conclusion that "one can know absolutely nothing" (quod nihil omnino contingeret scire). ${ }^{40}$ Beyond the a priori moment, an a posteriori or empirical moment is indispensable for the attainment of knowledge. In order to know, that is, the intellect must not only turn itself toward the rationes aeternae, but it must also proceed using essences abstracted from experience. ${ }^{41}$ In this context, the ideas are not the obiectum quod of human knowledge-not that what we can perceive-but only the obiectum quo-that through whose influence we attain certainty. The ideas, insofar as they can be grasped at all by the human intellect, can only be grasped reflexively by it. As formal principles of knowing, they first guarantee certainty on the part of both the objects and subjects of knowledge. But the specifying properties and material principles arise out of experience. 42

One sees the influence of the Aristotelian theory of knowledge which Bonaventure discusses in considerable detail in the opposita of the fourth question on the knowledge of Christ. In so doing, he arrives at a distinctive solution that thoroughly modifies the received Augustinian conception. ${ }^{43}$

39. Quaestiones disputatae de scientia Christi qu. 4 c, V 24a: "Creatura enim comparatur ad Deum in ratione vestigii, imaginis et similitudinis. In quantum vestigium, comparatur ad Deum ut ad principium; in quantum imago, comparatur ad Deum ut ad obiectum; sed in quantum similitudo, comparatur ad Deum ut ad donum infusum. Et ideo omnis creatura est vestigium, quae est a Deo; omnis est imago, quae cognoscit Deum; omnis et sola est similitudo, in qua habitat Deus." Questiones disputatae de scientia Christi qu. 4c, V 24a: "In opere vero, quod est a creatura per modum imaginis, cooperatur Deus per modum rationis moventis; et tale est opus certitudinalis cognitionis, quod quidem non est a ratione inferiori sine superiori."

40. Quaestiones disputatae de scientia Christi qu. 4 c, V 23a.

41. Quaestiones disputatae de scientia Christi qu. 4 c, V 224b. "Rursus, quia non ex se tota est anima imago, ideo cum his attingit rerum similitudines abstractas a phantasmate tanquam proprias et distinctas cognoscendi rationes, sine quibus non sufficit sibi ad cognoscendum lumen rationis aeternae, quamdiu est in statu viae."

42. Quaestiones disputatae de scientia Christi qu. 4 c, V 23b-24a; see further the quaestiones "de ideis" in 1 Sent $\mathrm{d} 35$ a 1, I 600-616, in particular 1 Sent $\mathrm{d} 35$ a 1 q 3 c, I 608a: "Idea significat divinam essentiam in comparatione sive in respectu ad creaturam. Idea enim est similitudo rei cognitae, quae quamvis in Deo sit absolutum, tamen secundum modum intelligendi dicit respectum medium inter cognoscens et cognitum."

See also Speer, Triplex veritas, pp. 97-102.

43. Compare the detailed discussion of the "rationes Augustini," esp. 1-8, V 17a-18a, and the "obiecta Aristotelis," esp. 7-16, V 21b-22a, in the beginning of the fourth question on the knowledge of Christ and the corresponding replies, ad 7-16, V 25a-b. 


\section{ILLUMINATIO}

As we follow Bonaventure's path of thought, it comes as no surprise that light figures prominently in its epistemological and metaphysical contexts. Recall that Bonaventure mentioned "being illumined by the spiritual radiation" as one of the conditions for a true understanding of an exemplaristic metaphysics. ${ }^{44}$ His motif of light invokes the Neoplatonic tradition. His reading of Augustine leads him, moreover, to speak of light as the cause of a kind of similarity. Following Pseudo-Dionysius and certain biblical texts, Bonaventure also speaks of light as a means of unification. Both ways of speaking hearken back to the Evangelist John's equation of light, truth and life. ${ }^{45}$

Bonaventure clearly speaks of light in many different contexts and in as any different ways. ${ }^{46}$ Let me give some examples. In his De reductione artium ad theologiam, Bonaventure describes a four-fold illumination emanating from a fountain-like source (fontalis lux). This introduces a comprehensive division of the sciences, which rests on distinction between illumination from "outside," from "underneath," from "inside" and "above". 47 The structure of the Collationes in Hexaemeron is itself built on a six-fold ordering of vision (visio), beginning with the natural light (lumen naturale) derived from the "facta est lux" of Genesis, and culminating in the seventh vision of the glorification of the soul. ${ }^{48}$ Philosophy is associated with the lumen naturale. In the fourth Collation-the one bearing on the

44. Cf. Collationes in Hexaemeron 1, 17, V 332b; cf. n. 18.

45. See in general, Josef Koch, "Über die Lichtsymbolik im Bereich der Philosophie und der Mystik des Mittelalter," Studium Generale 13 (1960): 653-70, rptd. in Kleine Schriften I, ed. K. Bormann (Roma: 1973), pp. 27-67, esp. pp. 27-31; Klaus Hedwig, Sphaera lucis. Studien zur Intelligibilität des Seienden im Kontext der mittelalterlichen, Lichtspekulation, BGPhThMA, N.F. 18 (Münster, 1980) pp. 23-45.

46. The following examples are focused on the epistemological aspect of light. For the question of the physical light and how both aspects are interconnected, see Hedwig, Sphaera lucis, pp. 161-72; and Emery, Jr., "Reading the World Rightly and Squarely," pp. 201-6.

47. De reductione artium ad theologiam 1, V 319a: "Omne datum optimum et omne donum perfectum desursum est, descendens a Patre luminum', Iacobus in Epistolae suae primo capitulo. In hoc verbo tangitur origo omnis illuminationis, et simul cum hoc insinuatur multiplicis luminis ab illa fontali luce liberalis emanatio. Licet autem omnis illuminatio cognitionis interna sit, possumus tamen rationabiliter distinguere, ut dicamus, quod est lumen exterius, scilicet lumen artis mechanicae; lumen inferius, scilicet lumen cogitionis sensitivae; lumen interius, scilicet lumen cognitionis philosophicae; lumen superius, scilicet lumen gratiae et sacrae Scripturae."

48. Collationes in Hexaemeron 3,24-31, V 347a-348b; see in particular 3,24, V 347a: "Praeter has est visio sextuplex, quae respondet operibus sex dierum; quibus minor mundus fit perfectus, sicut maior mundus sex diebus. Est visio intelligentiae per naturam inditae, et visio intelligentiae per fidem sublevatae, per Scripturam eruditae, per contemplationem suspensae, per prophetiam illustratae, per raptum in Deum absorptae. Ad has sequitur visio septima animae glorificatae, quas omnes habuit Paulus." 
first vision of the natural light-Bonaventure gives a divisio philosophiae. It is based on the three primary rays of the light of the first and highest truth (tres radii primae veritatis) - a truth which can neither be denied nor conceptualized as non-existing. ${ }^{49}$ This passage recalls the question discussed above concerning that which is understood first by the human intellect. Within his model of the three-fold truth-the truth of the beings (veritas rerum), moral truth (veritas morum), and the truth of language (veritas vocum)-Bonaventure integrates two rival models for the division of the sciences, the Aristotelian/Boethian divisio and the Platonic/Stoic divisio. Philosophy is, Bonaventure reminds us, the true love of wisdom. It is also the science of all sciences (ars artium). As such, it encompasses both the Aristotelian/Boethian division of philosophy into theology, mathematics, and physics, and the Platonic/Stoic division into physics, logic, and ethics. The science of sciences also encompasses the seven arts. ${ }^{50}$ To trace out and expound Bonaventure's hierarchy of the sciences and its epistemological foundations would be a study unto itself. 51

We return to Bonaventure's disputed questions on the knowledge of Christ by way of this claim: the doctrine of illumination allows Bonaventure to develop an epistemology rooted in exemplarism and the theory of ideas. Generally speaking, light figures as a "metaphysical conjecture" about the truth of things as well as a "model" for the relation between unity and plurality, between the absolute and the conditioned, between ancestor and descendant. ${ }^{52}$ In order to illustrate this, Bonaventure takes over from Augustine the example of the godless person who can think a concept like eternity and judge rightly regarding rules of practical living. What makes

49. Collationes in Hexaemeron 4,1-2 V 349ab: "Lux animae veritas est; haec lux nescit occasum. Ita enim fortiter irradiat super animam, ut etiam non possit cogitari non esse nec exprimi, quin homo sibi contradicat: quia, si veritas non est, verum est veritatem non esse: ergo aliquid est verum; et si aliquid est verum, verum est veritatem esse: ergo si veritas non est, veritas est. 'Super omnia enim praevalet veritas', ut dicitur in Esdra. Emittit autem haec lux tres radios primos; unde in Ecclesiastico: 'Tripliciter sol exurens montes'. Est enim veritas rerum, veritas signorum seu vocum et veritas morum. Veritas rerum est indivisio entis et esse, veritas sermonum est adaequatio vocis et intellectus, veritas morum est rectitudo vivendi. Et istae sunt tres partes philosophiae."

Cf. Collationes in Hexaemeron 5,22, V 357b. Concerning the foundation and the explication of Bonaventure's conception of truth, see Speer, Triplex veritas, esp. chap. 3, pp. 37-52.

50. See the table at the end of the article. Concerning the divisio philosophiae, see J. A. Weisheipl, "Classification of the Sciences in Medieval Thought," Medieval Studies 27 (1965): 54-90, esp. pp. 62-64; see also Andreas Speer, Die entdeckte Natur. Untersuchungen zu Begrüundungsversuchen einer "scientia naturalis" im 12. Jahrhundert, Studien und Texte zur Geistesgeschichte des Mittelalters 45, (New York: 1995), pp. 124-25, and n. 181.

51. My doctoral dissertation (see n. 26) attempted something like this, focusing on Bonaventure's notion of the three-fold truth (triplex veritas).

52. See Hans Blumenberg, "Licht als Metapher der Wahrheit," Studium Generale 10 (1957): 432-47; Hedwig, Sphaera lucis, pp. 161-65. 
the godless person capable of such things? The fact that in doing so "he turns himself to that light by which he is always touched, even when he turned himself away from it." 53 The problem of certainty here emerges once again, since Bonaventure sees, with Augustine, the cause of the pagan's knowledge as lying within rules "that are written down in the book of that light which is called Truth." 54 These rules are obviously in force quite independently of mistakes on the part of the knower. 55 The metaphor of illumination thus stresses the non-empirical origin of certain judgments. Not all human knowledge has its origin in experience or can be taken as the outcome of a process of abstraction. Although Bonaventure stipulates, for the possession of perfect knowledge, the need to trace things back "to an altogether unchangeable and fixed truth as well as to an altogether infallible light" ( recursus ad veritatem omnino immutabilem et stabilem et ad lucem omnino infallibilem), 56 the influence of the light can nevertheless not be seen as having general application. This divine light is not a cause of, say, wealth, in the same way that, for Bonaventure, this light is a cause of knowledge. At the same time, the light of illumination should not be seen as exclusively exceptional or special, as if all knowledge was infused and no knowledge was acquired or innate. ${ }^{57}$ The epistemological problematic in the theory of illumination thus becomes especially pronounced when focused on the individual subject. How are we to conceive concretely of the cooperation of the infallible light of truth? I cannot answer this question satisfactorily at present; however, I can suggest how Bonaventure opens manifold possibilities for a nuanced reply by distinguishing carefully between a created standard (ratio creata) and an eternal standard (ratio aeterna), between the light of the creature (lux creaturae) and the infallible light (lux infallibilis),

53. Quaestiones disputatae de scientia Christi qu. 4 c, V 236b: "Et hoc est quod Augustinus insinuat decimo quarto de Trinitate, capitulo decimo quinto: 'Commemoratur impius, ut convertatur ad Dominum tanquam ad eam lucem, qua etiam, cum ab illo averteretur, quodam modo tangebatur. Nam hinc est, quod et impii cogitant aeternitatem et multa recte reprehendunt recteque laudant in hominum moribus'." Cf Augustin, De Trinitate XIV, 15,21 (CCSL 50A, 451, 35-39).

54. Quaestiones disputatae de scientia Christi qu. 4 c, V 23b: Ubi et subdit, quod hoc faciunt per regulas, quae 'scriptae sunt in libro lucis illius, quae veritas dicitur'." Cf. Augustine, De Trinitate XIV,15,21 (CCSL 50A, 451,49-50).

55. Quaestiones disputatae de scientia Christi qu. 4 c, V 23b: "Quod autem mens nostra in certitudinali cognitione aliquo modo attingat illas regulas et incommutabiles rationes, requirit necessario nobilitas cognitionis et dignitas cognoscentis."

56. Quaestiones disputatae de scientia Christi qu. 4 c, V 23b.

57. Quaestiones disputatae de scientia Christi qu. 4 c, V 23ab: "Praeterea, illa lucis influentia aut est generalis, quantum Deus influit in omnibus creaturis, aut est specialis, sicut Deus influit per gratiam. Si est generalis: ergo Deus non magis debet dici dator sapientiae quam fecundator terrae, nec magis ab eo diceretur esse scientia quam pecunia; si specialis, cuiusmodi est in gratia: ergo secundum hoc omnis cognitio est infusa, et nulla est acquisita vel innata; quae omnia sunt absurda. Et ideo est tertius modus intelligendi, quasi medium tenens inter utramque viam" (see also n. 37). 
between a lower reason (ratio inferior) and a higher reason (ratio superior), and between created wisdom (sapientia creata) and uncreated wisdom (sapientia increata). To clarify the relationship and the tension within this twofold structure constitutes one of the main challenges for students of Bonaventure's thought. It is a feature of his thought that figures with particular importance in his later works-one which shows perhaps the strongest influence of the Victorine tradition. ${ }^{58}$

\section{REDUCTIO}

Within Bonaventure's concept of metaphysics, reductio is, in a certain respect, the complement of illuminatio. One way to be moved intellectually is to be moved by what Bonaventure calls "spiritual radiation"; its complement is to be "reduced to the highest." 59 These terms suggest why we might not understand reductio in a purely technical or formalistic sense. Here again, one recognizes Bonaventure's epistemological approach, his analysis of the concepts, and of understanding in the manner of a naturalis resolutio in order to disclose the metaphysical constitution of beings. ${ }^{60}$ In the first book of his commentary on the Sentences, Bonaventure distinguishes the intellectus apprehendens, or "receiving intellect," from the intellectus resolvens, the analyzing intellect. The intellect does not proceed by simply accumulating data, adding one item of information to another. Instead, it regards the essence of beings, which is to say, it understands effects together with their underlying causes. Thus, the intellect no longer perceives the single thing, rather, it understands how beings are interconnected and related to their common goal. ${ }^{61}$ The first

58. See Andreas Speer, "The Certainty and Scope of Knowledge: Bonaventure's 'Disputed Questions on the Knowledge of Christ,'” Medieval Philosophy and Theology 3 (1993):35-61, esp. pp. 50-55.

59. Collationes in Hexaemeron 1, 17 V 332b; cf. n. 18.

60. Regarding the tradition of the "naturalis resolutio" see Ludger Oeing-Hanhoff, "Analyse/Synthese," in Historisches Wörterbuch der Philosophie I, pp. 232-48.

61. 1 Sent d 28 dub 1, I 504a: "Sed quod possit intelligi aliquid praeter alterum, hoc potest esse multipliciter: aut quantum ad intellectum apprehendentem, aut quantum ad intellectum resolventem. Si primo modo, sic non potest intelligi sine aliquo, quod est ei ratio intelligendi, sicut Deus praeter deitatem, et homo praeter humanitatem; potest tamen intelligi effectus, non intellecta causa, et inferius, non intellecto superiori, quia potest quis apprehendere hominem, non intellecto aliquo superiorem. Et sic dicit Philosophus, quod, quo unum dicit, quodam modo multa dicit, non simpliciter, sed quodam modo, quia implicite. Alio modo contingit aliquid intelligere praeter alterum, intellectu resolvente; et iste intellectus considerat ea quae sunt rei essentialia, sicut potest intelligi subiectum sine propria passione. Et hoc potest esse dupliciter: aut intellectu resolvente semiplene, potest intelligi aliquid esse, non intellecto primo ente. Intellectu autem resolvente perfecte, non potest intelligi aliquid, primo ente non intellecto." 
step of such a reflexive analysis of knowledge is an analysis of concepts which explicates what is implicit and undiscovered in what is known. In the third chapter of his Itinerarium mentis in Deum (Mind's journey to God) Bonaventure speaks of the operation of the intellect as that of perceiving concepts, sentences, and conclusions. The intellect understands the signification of the concepts which comprehend the definition of each being. It is characteristic of definitions that the definiens is placed over the definiendum and is given in more general terms; every definition of a special substance (specialis substantia) requires common concepts and, in the end, the first principle of all being, the ens per se, in order to be perfectly understood. ${ }^{62}$ Therefore reductio does not lead to the "common" but to the "first" one. It is only in a secondary sense that being-as-such can be understood as a common concept, that is, insofar as being encompasses all that is. Here the doctrine of the transcendentals fits into the analysis of the intellectus plene resolvens, but in a very exemplary manner (and in a way very different, for example, from Thomas Aquinas), referring to the doctrine of Alexander of Hales. ${ }^{63}$ If the analysis of the intellect actually proceeds to its very end, then perceiving the transcendentals as the first common concepts, the "conditiones entis," cannot conclude the analysis. Such analysis would only be "semiplene," more or less perfect. For being can be understood as incomplete or as complete, as imperfect or as perfect, as contingent or as per se, and so on. Here Bonaventure foreshadows the doctrine of the so-called "disjunctive transcendentals" which Duns Scotus would later develop. ${ }^{64}$ Moreover, as Bonaventure observes quoting Averroes, privations and defects can only be comprehended by reference to affirmative "modes" (positiones). Perfect and complete understanding includes the knowledge of a "eternal being as such" in its very end,

62. Itinerarium mentis in Deum 3,3, V 304a: "Operatio autem virtutis intellectivae est in perceptione intellectus terminorum, propositionum et illationum. Capit autem intellectus terminorum significata, cum comprehendit, quid est unumquodque per definitionem. Sed definitio habet fieri per superiora, et illa per superiora definiri habent, usquequo veniatur ad suprema et generalissima, quibus ingoratis non possunt intelligi definitive inferiora. Nisi igitur cognoscatur, quid est ens per se, non potest plene sciri definitio alicuius specialis substantiae."

63. See in particular Alexander Halensis, Summa theologica lib. I, tr. 3, c. 1-2 nn. 72-73, ed. Quaracchi I, pp. 112-16. See on this point Aertsen, Medieval Philosophy and the Transcendentals, pp. 40-48 (to Alexander of Hales) and, with regard to the general account of Thomas Aquinas, 71-77; see also Jan A. Aertsen and Andreas Speer, "Die Philosophie Bonaventuras und die Transzendentalienlehre," Recherches de Théologie et Philosophie médiévales LXIV 1(1997) pp. 40-74.

64. Itinerarium mentis in Deum 3,3, V 304a: "Nec ens per se cognosci potest, nisi cognoscatur cum suis conditionibus, quae sunt: unum verum bonum. Ens autem, cum possit cogitari ut diminutum et ut completum, ut imperfectum et ut perfectum, ut ens in potentia et ut ens in actu, ut ens secundum quid et ut ens simpliciter, ut ens in parte et ut ens totaliter, ut ens transiens et ut ens manes, ut ens per aliud et ut ens per se, ut ens permixtum non-enti et ut ens purum, ut ens dependens et ut ens absolutum, ut ens posterius et ut ens prius, ut ens mutabile et ut ens immutabile, ut ens simplex et ut ens compositum." 
i.e., being that "possesses the "rationes" of all beings in its purity." 65 Through the ideas ("rationes") created and imperfect beings are related to divine being. The idea, as an element of ratio aeterna, must be primarily understood as assimilating things to God. 66 With reference to a full and certain understanding of a single being, in the context of the disputed questions on Christ's knowledge, reductio means to understand this single being not only as such (in se), nor as it is in the soul (in anima), but also and especially insofar it is in the eternal standard (in arte aeterna), also known as the eternal creative art. 67 Therefore, in light of the fact that things are considered according to their conceptual and specific mode of existence, as a kind of trace, image or similitude (secundum vestigium, imaginem et similitudinem), 68 they belong also to this kind of fundamental epistemological analysis, that is to this reductio. Reductio leads back to the basic problem of the certainty of knowledge, connecting this question with an exemplaristic concept of metaphysics founded in the true understanding of the first and most perfect being as the first understood and the highest principle both of the order of knowledge and of the order of being.

\section{SCIENTIA VERITATIS UT SCRUTABILIS CERTA}

I close with some summary reflections. First, in my estimation, one cannot deny that there is a philosophy in Bonaventure. We have seen some of its central ideas and their main sources. Recall Dante's presentation of

65. Itinerarium mentis in Deum 3,3, V 304a: "Cum 'privationes et defectus nullatenus possint cognosci nisi per positiones' [Averroes, In III de animal tex. 25], non venit intellectus noster ut plene resolvens intellectum alicuius entium creatorum, nisi iuvetur ab intellectu entis purissimi, actualissimi, completissimi et absoluti; quod est ens simpliciter et aeternum, in quo sunt rationes omnium in sua puritate."

See Stephen F. Brown, ed., Bonaventure: The Journey of the Mind to God, trans. Philoteus Boehner, (Cambridge. 1990), pp. 19-20, 61-62 nn.

66. 1 Sent d 36 a 3 q 2 c, I 629b: "Unde notandum, quod idea, sicut supra dictum fuit in quaestione de ideis, dicit assimilationem extra genus. Prima autem assimilatio est in ratione entitatis in Deo. Omne ergo quod de se dicit rationem entitatis, sive sit compositum, sive imperfectum, sive materiale, sive passibile, sive in actu, sive in potentia, potest Deo assimilari et produci; et ideo habet esse in Deo."

67. Quaestiones disputatae de scientia Christi qu. 4 c, V 23b-24a: "Si ergo ad plenam cognitionem fit recursus ad veritatem omnino immutabilem et stabilem et ad lucem omnino infallibilem; necesse est, quod in huiusmodi cognitione recurratur ad artem supernam ut ad lucem et veritatem: lucem, inquam dantem infallibilitatem scienti, et veritatem dantem immutabilitatem scibili. Unde cum res habeant esse in mente et in proprio genere et in arte aeterna, non sufficit ipsi animae ad certitudinalem scientiam veritas rerum, secundum quod esse habent in se, vel secundum quod esse habent in proprio genere, quia utrobique sunt mutabiles, nisi aliquo modo attingat eas, in quantum sunt in arte aeterna."

68. Quaestiones desputate de scientia Christi qu. 4 c, (V. 24a), see n. 39. 
Bonaventure's companions in the twelfth canto of the Paradiso. ${ }^{69}$ I want to call attention to Anselm, Hugh of St. Victor, and Joachim of Fiore, for these individuals represent three main characteristics of Bonaventure's thought: its search for the necessary foundation of human knowledge, its speculative scope, and its emphasis on salvation history. I have spoken here predominantly of the Anselmian Bonaventure. We may take this as a partial answer as to the place of philosophy in Bonaventure's thought.

My picture is, admittedly, one-sided; it downplays, for example, the poetic character of Bonaventure's writing, what is often called the "mystic" or "spiritual" part of his oeuvre. We should, however, as Dante warns us, be wary of a sharp distinction between the spiritual and the intellectual. In the eleventh canto of the Paradiso, following the custom of both orders to celebrate the Feast Days of the founders of their orders, Dante has the Dominican Aquinas praise Francis, and in the following canto, the Franciscan Bonaventure praise Dominic. In this way, Dante not only passes an interesting judgement with respect to the ecclesiastical rivalries of his time, he also suggests that love and knowledge- "seraphic ardor" and "cherubic light"-are one in God, so that "to praise one, whichever we take, is to speak of both."70 In Bonaventure, indeed, the search for certainty and for the limits of knowledge stand together, since the summit of human knowing is only attained in spiritual contemplation.

But what does this mean for the question of philosophy and theology? There is no doubt that Bonaventure thought of himself as a theologian, and was, moreover, seen by his contemporaries as a theologus. But, keeping in mind the whole history of philosophy, we should not neglect the fact that the model of philosophy which celebrates the so-called "autonomy of philosophical thought" is itself an historically-contingent model. Can one credibly speak of "pure philosophical thought" in Aristotle, Averroes, or Albert the Great? Do they possess authority as philosophers only insofar as they fit into a particular cultural and scientific background-say that of non-clerical masters in the Parisian Faculty of Arts? As much as we like to believe that philosophy is "independent" today, when you come right down to it, who is really interested in the glass bead games we play? Perhaps modern enlightened philosophers are little more than the magistri ludi of a very difficult game, the game that begins with the question: How can we understand reality and the fact that we are? Might the vaunted "independence" of philosophy today amount to little more than a confession that the leaders of other disciplines-the physicists for example or the economists-are the ones telling the stories that really "work" for contemporary society? Philosophers are left, in their "autonomy" and "inde-

69. Dante, La Commedia divina, Paradiso XII, 133-41.

70. Dante, La Commedia divina, Paradiso XI, 37-39: "L'un fu tutto serafico in ardore;/l'altro per sapienza in terra fue di cherubica luce uno splendore." Cf. Etienne Gilson, Dante the Philosopher (London: 1948), pp. 242-53. 
pendence," to play a complicated game that means little to anyone apart from the players themselves. ${ }^{71}$

Bonaventure, as we have seen, relates philosophy to theology. Reducing this relationship to the ancilla (or handmaid) model seems insufficient to explain the place of philosophy within the whole sweep of Bonaventure's thought. We have seen that Bonaventure recognized the indisputable need for a philosophical analysis of theology. This analysis is-especially with regard to metaphysics-conceptualized as a fundamental critique of the scope and certainty of human knowledge. ${ }^{72}$ Every science based on reason stands under the verdict of fallibilism. Although Bonventure underscores the finitude of human knowledge, he does not mean to deny the validity of the use of reason in respect to certain objects. There is a wide field for the positive autonomy of scientific rationality, as Bonaventure explains in the fourth collation of his Hexaemeron, with his model of the three-fold truth in the horizon of the natural light.

The Hexaemeron, as Joseph Ratzinger has suggested, represents a specific kind of theological synthesis from the perspective of a history of salvation. ${ }^{73}$ But in over-emphasizing its antiphilosophical character, in dwelling on its opposition between the "truth of salvation" to the "pure truth of reason," Ratzinger misses Bonaventure's point that, given the epistemological criteria Bonaventure articulates in this text, even theology must be seen as but a provisional kind of knowing.

This model is still present, albeit in very concise form, in the Collationes de septem donis Spiritus sancti, (the Collations on the Seven Gifts of the Holy Spirit) where Bonaventure develops a four-tiered account of knowledge. ${ }^{74}$ Philosophical knowledge deals with a knowledge of the truth that can be scrutinized as "certain knowing" (ut scrutabilis notitia certa). ${ }^{75}$ Theological

71. The centennial exhibition "Books of the Century" at the New York Public Library provides a striking corroboration of the diminished influence of philosophy. Philosophy is represented on this list by a single title-Sartre's L'être et les néants - under the heading "Mind and Spirit." By contrast "Economics and Technology" constitutes a heading of its own. One may also find titles like J. R. R. Tolkien's The Hobbit and A. A. Milne's wonderful book Winnie-the Pooh.

72. See Bonaventure critique with respect to the "philosphi," who cannot give the promised tenth science: contemplation and wisdom. Collationes in Hexaemeron 4, 1, V 349a: "Et sic possent explicari omnes difficultates philosophiae. Philosophi dederunt novem scientias et polliciti sunt dare decimam, scilicet contemplationem. Sed multi philosophi, dum se voluerunt dividere a tenebris erroris, magis erroribus se immiscuerunt." Cf. also Collationes in Hexaemeron 5,22, V 357b. See Speer, "Metaphysica reducens," pp. 177-80.

73. See Ratzinger, Die Geschichtsphilosophie des hl. Bonaventura, esp. pp. 148-49; Speer, Triplex veritas, pp. 224-30.

74. Collationes de septem donis Spiritus sancti 4,5, V 474b: "Scientia philosophica nihil aliud est quam veritatis ut scrutabilis notitia certa. Scientia theologica est veritatis ut credibilis notitia pia. Scientia gratuita est veritatis ut diligibilis notitia sancta. Scientia gloriosa est veritatis ut desiderabilis notitia sempiterna." See also the table at the end of the article.

75. Collationes de septem donis Spiritus sancti $4,6, \mathrm{~V} 474 \mathrm{~b}$ and 77. 


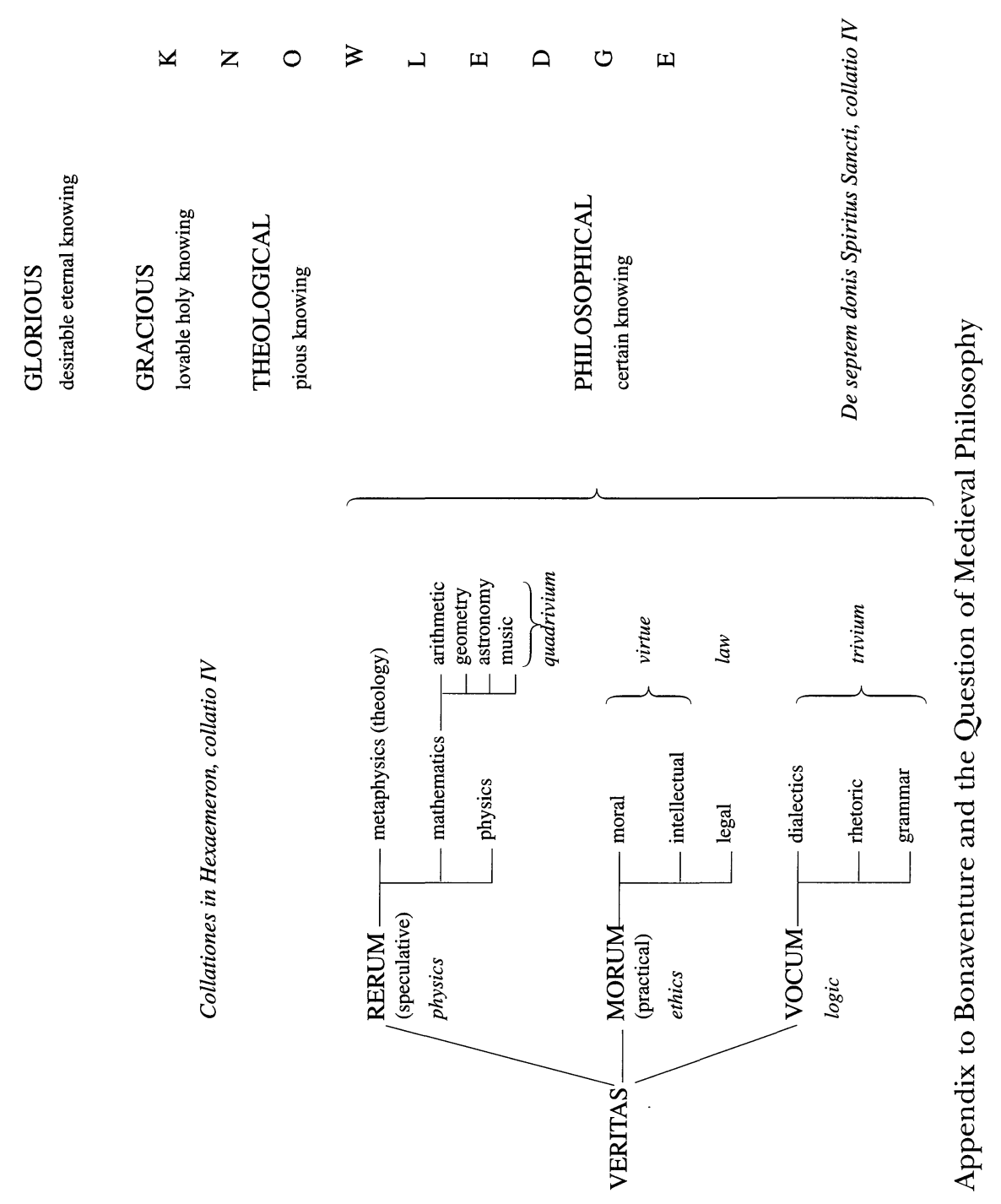


knowledge contains a knowledge of truth that is worthy of belief by "pious knowing" (ut credibilis notitia pia). ${ }^{76}$ In addition to these, Bonaventure speaks of "gracious" and "glorious" knowledge. The former is based on a knowledge of truth rooted in a "lovable holy knowing" (ut diligiblis notitia sancta). ${ }^{77}$ The latter is related to a way of knowing the truth which Bonaventure calls "desirable eternal knowing" (ut desiderabilis notitia sempiterna). ${ }^{78}$ Utilizing this four-fold distinction, Bonaventure carefully explains the scope of each kind of knowledge and also of the related sciences. It is remarkable that the role of philosophy is not contested here. Quite the contrary: philosophy obtains again the position of a speculative theology, in the tradition of the Boethian notion of theologia, while theology, by comparison, becomes scriptural theology or exegesis. Bonaventure thus opens anew a debate about the character of theology vis-à-vis philosophy. A point of reference for this debate can be seen in Meister Eckhart's unfinished project of the Opus tripartitum, a work which integrates metaphysics, speculative theology, and scriptural exegesis within a unifying hermeneutics and follows the twelveth-century model of a deductive or axiomatical theology. 79

76. Collationes de septem donis Spiritus 4,13, V 476a and 77.

77. Collationes de septem donis Spiritus 4,19, V 477b and 77.

78. Collationes de septem donis Spiritus 4,25, V 479ab.

79. See Wouter Goris, "'Prout iudicaverit expedire'. Zur Interpretation des zweiten Prologs zum 'Opus expositionum' Meister Eckharts," Medioevo 20 (1995): 233-78. 